\title{
Attenuation of Angiotensin II- and III-induced Aldosterone Release by
}

\section{Prostaglandin Sỷnthesis Inhibitors}

\author{
William B. Campbell, Celso E. Gomez-Sanchez, Beverley V. Adams, \\ James M. SChMITZ, and HAROLd D. ITSKovitz, Departments of Pharmacology \\ and Internal Medicine, University of Texas Health Science Center, \\ Dallas, Texas 75235; Medical College of Wisconsin, Milwaukee County \\ General Hospital, Milwaukee, Wisconsin 53233
}

A B S T RACT The effect of two prostaglandin synthesis inhibitors, indomethacin and meclofenamate, on angiotensin II (AII)- and III (AIII)-induced aldosterone release was studied in normal and sodiumdepleted conscious rats and in adrenal capsular cell suspensions obtained from normal rats. In normal rats, in vivo AII and AIII were equipotent in causing doserelated increases in serum aldosterone concentrations. Indomethacin decreased the basal serum aldosterone levels by $50 \%$ and serum renin levels by $43 \%$. In addition, the steroidogenic effects of AII and AIII were reduced by 45 and $63 \%$ with $3 \mathrm{mg} / \mathrm{kg}$ of indomethacin and 63 and $73 \%$ with $10 \mathrm{mg} / \mathrm{kg}$, respectively. In contrast, meclofenamate failed to alter basal serum levels of aldosterone or AII-stimulated aldosterone release but inhibited serum renin levels by $27 \%$ and the aldosterone-stimulating effect of AIII by $99 \%$. Indomethacin $(3 \mathrm{mg} / \mathrm{kg})$ and meclofenamate $(2 \mathrm{mg} / \mathrm{kg})$ inhibited urinary prostaglandin $(\mathrm{PG}) \mathrm{E}_{2}$ and $\mathrm{PGF}_{2 \alpha}$ excretion by 63 and $52 \%$ and 37 and $31 \%$, respectively. Both inhibitors significantly decreased the adrenal capsular $\mathrm{PGE}_{2}$ and $\mathrm{PGF}_{2 \alpha}$ content and the conversion of $\left[{ }^{14} \mathrm{C}\right]$ arachidonate to $\left[{ }^{14} \mathrm{C}\right] \mathrm{PGE}_{2}$ and $\left[{ }^{14} \mathrm{C}_{3} \mathrm{PGF}_{2 \alpha}\right.$. In sodium-depleted rats, indomethacin produced similar effects reducing the control serum aldosterone levels by $29 \%$, AII-stimulated aldosterone by $47 \%$, and completely suppressing the aldosterone response to AIII without altering serum renin activity. In adrenal cell suspensions, similar results were observed with indomethacin inhibiting basal and AII- and AIII-stimulated aldosterone release by 29,81 , and $93 \%$, respectively. Meclofenamate failed to alter basal and AII-

Dr. Gomez-Sanchez is the recipient of a Research Career Development Award (KO4-HL00429).

Received for publication 22 May 1978 and in revised form 17 August 1979. stimulated aldosterone release but inhibited that stimulated by AIII by $86 \%$. The present findings suggest that prostaglandins modulate the effects of the renin-angiotensin system by stimulating the release of renin from the kidney and augmenting the steroidogenic effects of AII and AIII in the adrenal cortex.

\section{INTRODUCTION}

Recently, we have reported that both angiotensin II and III were equipotent in stimulating the release of aldosterone from the adrenal cortex; however, angiotensin III possessed only $30 \%$ of the pressor activity of angiotensin II $(1,2)$. These peptides were found to release prostaglandin (PG)E from the perfused kidney and mesenteric arterial vasculature (3-5). The released prostaglandins were vasodilators and antagonized the vasoconstriction caused by the angiotensins. Additionally, PGE stimulated the release of aldosterone from the adrenal, a property that was additive in effect with that of angiotensin II $(6,7)$. We, therefore, wondered if angiotensin II and III might simultaneously stimulate the release of aldosterone and $\mathrm{PGE}_{2}$ from the adrenal, and the released $\mathrm{PGE}_{2}$, acting as an intra-adrenal hormone, would also stimulate the release of aldosterone, thereby augmenting angiotensin-induced steroidogenesis. To test this hypothesis, the steroidogenic activity of angiotensin II and III were compared in conscious rats and adrenal cell suspensions in the presence and absence of the inhibitors of prostaglandin synthesis, indomethacin and meclofenamate (8).

\section{METHODS}

Male Sprague-Dawley rats (225-300 g) (Laboratory Supply Co., Indianapolis, Ind.) were used in the studies. The rats were maintained on Purina Laboratory Chow (Ralston 
Purina Co. Inc., St. Louis, Mo.) (150 meq Na/kg and 270 meq $\mathrm{K} / \mathrm{kg}$ ) and water ad lib. Sodium depletion was produced by placing the rats on a sodium-deficient diet containing 10 meq $\mathrm{Na} / \mathrm{kg}$ and 220 meq $\mathrm{K} / \mathrm{kg}$ (ICN Nutritional Biochemicals Div., Cleveland, Ohio) for $5 \mathrm{~d}$ and given furosemide $10 \mathrm{mg} / \mathrm{kg}$ i.p. the first $2 \mathrm{~d}$ of dietary alteration (2).

Conscious rats. Chronic catheters were placed in the jugular vein of rats 18-24 h before the experimental procedure $(1,2)$. Subsequently, angiotensin II, III (Beckman Instruments, Inc., Fullerton, Calif.), or 5\% dextrose (control) was infused intravenously at $50 \mu \mathrm{l} / \mathrm{min}$ for $20 \mathrm{~min}$ into the conscious rats. In the rats receiving the prostaglandin synthesis inhibitors, indomethacin (Sigma Chemical Co., St. Louis, Mo.) or meclofenamate (Parke-Davis \& Co., Detroit, Mich.) suspended in olive oil were given subcutaneously $100 \mathrm{~min}$ before the infusion of the peptides. At the end of the infusion period, the animals were killed by decapitation and the aortic blood $(4 \mathrm{ml})$ was collected in plastic tubes on ice. The serum was separated at $4^{\circ} \mathrm{C}$ and stored at $-20^{\circ} \mathrm{C}$ until assayed for renin and aldosterone.

An additional set of animals was placed in metabolic cages to allow urine collection. After $3 \mathrm{~d}$ of equilibration, an 8-h urine sample was collected from 0800 to 1600 . The urine was then filtered and stored at $-20^{\circ} \mathrm{C}$ until assayed for prostaglandins. The following day the rats were given indomethacin ( $3 \mathrm{mg} / \mathrm{kg}$ ) or meclofenamate $(2 \mathrm{mg} / \mathrm{kg}$ ) suspended in olive oil subcutaneously and the urine collections repeated during the same time period ( 0800 to 1600$)$ to eliminate any circadian variation.

Adrenal capsules. Both adrenal glands were removed from rats $90 \mathrm{~min}$ after pretreatment with either olive oil, indomethacin, or meclofenamate. The capsular tissue was removed and treated according to one of the following protocols: (a) Capsules from one rat were rapidly placed in cold $0.1 \mathrm{M}$

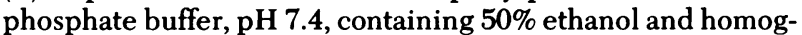
enized. The homogenate was centrifuged at $2,000 \mathrm{~g}$ for 20 min and the supernate assayed for prostaglandins. (b) Capsules from one rat were placed in $1 \mathrm{ml}$ of medium 199 (Grand Islands Biological Co., Grand Island, N. Y.) containing $2 \mathrm{mg} / \mathrm{ml}$ of bovine serum albumin (Sigma Chemical Co.), $4.5 \mathrm{meq} / \mathrm{liter}$ of potassium, and $2 \mu \mathrm{Ci}$ of $\left[{ }^{14} \mathrm{C}\right]$ arachidonic acid (New England Nuclear, Boston, Mass.). The capsules were then incubated for $2 \mathrm{~h}$ in a Dubnoff metabolic shaker at $37^{\circ} \mathrm{C}$ under an atmosphere of $95 \% \mathrm{O}_{2}$ and $5 \% \mathrm{CO}_{2}$. The supernate was then removed, acidified to $\mathrm{pH} 3$ with acetic acid, and extracted with $10 \mathrm{ml}$ of ethyl acetate. The ethyl acetate extract was dried at $30^{\circ} \mathrm{C}$ under a stream of nitrogen. The extract was then separated into its arachidonic acid and prostaglandin components by silicic acid chromatography (9). The column eluates were dried at $30^{\circ} \mathrm{C}$ with nitrogen, liquid scintillation fluid added, and counted in a Beckman liquid scintillation spectrometer (Beckman Instruments, Inc.).

Adrenal cell suspensions. Adrenal cell suspensions were prepared by the method of Sarstedt et al. (10) with several modifications. Rats were killed by decapitation, their adrenals removed, and the adrenals placed in potassium-free medium 199. The adrenals were separated from the adhering fat, and the capsules removed. The capsular tissue was minced and incubated in potassium-free medium 199 containing $0.5 \mathrm{mg} / \mathrm{ml}$ of trypsin (Sigma Chemical Co.) for $15 \mathrm{~min}$ in a Dubnoff metabolic shaker at $37^{\circ} \mathrm{C}$ under an atmosphere of $95 \% \mathrm{O}_{2}$ and $5 \% \mathrm{CO}_{2}$ at $60 \mathrm{rpm}$. The tissue was then washed twice with potassium-free medium 199 containing $2 \mathrm{mg} / \mathrm{ml}$ of bovine serum albumin and $1 \mathrm{mg} / \mathrm{ml}$ of lima bean trypsin inhibitor (Sigma Chemical Co.) The tissue was resuspended in medium 199 containing $1 \mathrm{mg} / \mathrm{ml}$ of collagenase (Worthington Biochemial Corp., Freehold, N. J.), $0.05 \mathrm{mg} / \mathrm{ml}$ of deoxyribonuclease (Sigma Chemical Co.), $0.05 \mathrm{mg} / \mathrm{ml}$ of ribonuclease
(Sigma Chemical Co.), and $2 \mathrm{mg} / \mathrm{ml}$ of bovine serum albumin and incubated for $1 \mathrm{~h}$ in a Dubnoff metabolic shaker at $37^{\circ} \mathrm{C}$ under $95 \% \quad \mathrm{O}_{2}$ and $5 \% \mathrm{CO}_{2}$ with $60 \mathrm{rpm}$ agitation. After 30 and $60 \mathrm{~min}$ of incubation, the cells were dispersed by repeated (30 times) pipetting. The suspension was then washed twice with potassium-free medium 199 containing $1 \mathrm{mg} / \mathrm{ml}$ of lima bean trypsin inhibitor and $2 \mathrm{mg} / \mathrm{ml}$ of bovine serum albumin and resuspended in medium 199 containing $4.5 \mathrm{meq} / \mathrm{liter}$ of potassium and $2 \mathrm{mg} / \mathrm{ml}$ of bovine serum albumin. The adrenal cells were counted with a hemocytometer and the number of viable cells determined by exclusion staining of tryptan blue. With this method, $\sim 300,000$ viable cells are obtained per adrenal capsule, and the viability of the cells is $\sim 94 \%$.

$0.5 \mathrm{ml}$ containing $500,000-700,000$ cells was then incubated for $1 \mathrm{~h}$ in a Dubnoff metabolic shaker at $37^{\circ} \mathrm{C}$ under an atmosphere of $95 \% \mathrm{O}_{2}$ and $5 \% \mathrm{CO}_{2}$. All compounds were added in a constant volume of $10 \mu \mathrm{l}$ and an equal volume of their vehicle was added to the control tubes. At the end of the incubation period, the cell suspensions were centrifuged and the supernate assayed for aldosterone by direct radioimmunoassay and in some cases $\mathrm{PGE}_{2}$. The results were expressed as nanograms of aldosterone per $10^{6}$ cells per hour.

Assays. Serum aldosterone concentrations were measured by radioimmunoassay, corrected for recoveries, and expressed as nanograms per deciliter (11). Serum renin activity was measured by the antibody trapping method of Poulsen and Jorgensen (12) and the results expressed as nanograms of angiotensin I generated per milliliter of serum per hour. Finally, urinary and adrenal $\mathrm{PGE}_{2}$ and $\mathrm{PGF}_{2 \alpha}$ were measured by radioimmunoassay after acid-lipid extraction and silicic acid chromatography (9). The $\mathrm{PGE}_{2}$ and $\mathrm{PGF}_{2 \alpha}$ antisera were produced in our laboratory in rabbits against a prostaglandinthyroglobulin conjugate according to the method of Jaffe and Behrman (13). The $\mathrm{PGE}_{2}$ antibody cross-reacted $50 \%$ with $\mathrm{PGE}_{1}$ and $<0.5 \%$ with $\mathrm{PGD}_{2}, \mathrm{PGF}_{2 \alpha}, \mathrm{PGB}_{2}, \mathrm{PGA}_{2}, 6$-keto$\mathrm{PGF}_{1 \alpha}$, and its 15-keto metabolites. The $\mathrm{PGF}_{2 \alpha}$ antibody showed a $100 \%$ cross-reaction with $\mathrm{PGF}_{1 \alpha}$, and $<0.5 \%$ crossreaction with $\mathrm{PGD}_{2}, \mathrm{PGE}_{2}, \mathrm{PGB}_{2}, \mathrm{PGA}_{2}, 6$ 6-keto- $\mathrm{PGF}_{1 \alpha}$, and its 15-keto metabolites. Urinary PGE was also measured by bioassay (3) after acid-lipid extraction, purification by thin-layer chromatography, and bioassay employing the rat stomach fundic strip, rat colon, and chick rectum.

When comparing groups, statistical analyses were performed with an analysis of variance and Student's $t$ test (14). When comparing dose-response curves, analysis of covariance. was used for statistical significance (14) and the $20 \%$ effective dose or concentrations giving a $20 \mathrm{ng} / \mathrm{dl}$ increase in serum aldosterone or $20 \mathrm{ng} / 10^{6} \mathrm{cells} / \mathrm{h}$ increase in media aldosterone concentration was used to compare potency of peptides.

\section{RESULTS}

Conscious rats. The effect of indomethacin on urinary prostaglandin excretion rate is shown in Table I. During the 8 -h period of urine collection, the excretion of $\mathrm{PGE}_{2}$ was $58.7 \pm 9.2 \mathrm{ng} / 8 \mathrm{~h}$ when measured by bioassay and $67.7 \pm 9.2 \mathrm{ng} / 8 \mathrm{~h}$ by radioimmunoassay. The urinary $\mathrm{PGE}_{2}$ excretion decreased by $>60 \%$ after indomethacin as measured by both techniques. Similarly, the excretion of $\mathrm{PGF}_{2 \alpha}$ was reduced by $52 \%(P<0.001)$ after indomethacin. Meclofenamate reduced the urinary excretion of $\mathrm{PGE}_{2}$ and $P F_{2 \alpha}$ by 37 and $31 \%$, respectively. The effect of the prostaglandin synthesis inhibitors administered in vivo 
TABLE I

Effect of Prostaglandin Synthesis Inhibitors on the Urinary Excretion of Prostaglandins

\begin{tabular}{cccc}
\hline & $\begin{array}{c}\text { PGE } \\
\text { (Bioassay) }\end{array}$ & $\begin{array}{c}\text { PGE }_{2} \\
\text { (Radioimmuno- } \\
\text { assay) }\end{array}$ & $\begin{array}{c}\text { PGF }_{2 a} \\
\text { (Radioimmuno- } \\
\text { assay) }\end{array}$ \\
\hline $\begin{array}{c}\text { Olive oil } \\
(1 \mathrm{ml} / \mathrm{kg}, \text { s.c.) }\end{array}$ & $58.7 \pm 9.2$ & $67.7 \pm 9.2$ & $29.4 \pm 2.2$ \\
$\begin{array}{c}\text { Indomethacin } \\
(3 \mathrm{mg} / \mathrm{kg}, \text { s.c.) }\end{array}$ & $18.8 \pm 3.1^{*}$ & $25.1 \pm 1.9 \ddagger$ & $14.2 \pm 1.3 \ddagger$ \\
$\begin{array}{c}\text { Meclofenamate } \\
(2 \mathrm{mg} / \mathrm{kg}, \text { s.c.) }\end{array}$ & - & $42.6 \pm 4.5^{*}$ & $20.2 \pm 3.2^{*}$ \\
\hline
\end{tabular}

Values are expressed as the mean \pm SEM for six animals.

$* P<0.05$.

$\ddagger P<0.001$.

on adrenal capsular prostaglandin content was also determined (Table II). Indomethacin and meclofenamate significantly decreased the $\mathrm{PGE}_{2}$ content by 76 and $55 \%$, respectively, and the $\mathrm{PGF}_{2 \alpha}$ content by 75 and $70 \%$, respectively. Also, the conversion of $\left[{ }^{14} \mathrm{C}\right]-$ arachidonic acid to $\left[{ }^{14} \mathrm{C}\right] \mathrm{PGE}_{2}$ and $\left[{ }^{14} \mathrm{C} \mathrm{PGF}_{2 \alpha}\right.$ was decreased by $32 \%$ with indomethacin and $50 \%$ with meclofenamate (Table II). The decreased adrenal prostaglandin content and decreased conversion of $\left[{ }^{14} \mathrm{C}\right]$ arachidonate to $\left[{ }^{14} \mathrm{C}\right] \mathrm{PGE}_{2}$ and $\left[{ }^{14} \mathrm{C}\right] \mathrm{PGF}_{2 \alpha}$ by indomethacin and meclofenamate indicates that in the doses employed, these drugs are active as inhibitors of adrenal prostaglandin synthesis in vivo.

The prostaglandin synthesis inhibitors also significantly reduced the release of renin (Table III). Indomethacin reduced the serum renin activity by $43 \%$

TABLE II

Effect of Prostaglandin Synthesis Inhibitors on Prostaglandin Content and $\left[{ }^{14} \mathrm{C}\right]$ Arachidonic Acid Metabolism in Rat Adrenal Capsules

\begin{tabular}{|c|c|c|c|c|}
\hline \multirow[b]{2}{*}{ Treatment } & \multicolumn{2}{|c|}{$\begin{array}{c}\text { Adrenal capsular } \\
\text { prostaglandin content }\end{array}$} & \multicolumn{2}{|c|}{$\begin{array}{c}\text { Conversion of } \\
{\left[{ }^{14} \mathrm{C}\right] \text { arachidonic acid to }} \\
{\left[{ }^{14} \mathrm{C}\right] \text { prostaglandin }}\end{array}$} \\
\hline & $\mathrm{PGE}_{2}$ & $\mathrm{PGF}_{2 a}$ & $\mathrm{PGE}_{2}$ & PGF $_{2 \alpha}$ \\
\hline & \multicolumn{2}{|c|}{ pg/2 capsules } & \multicolumn{2}{|c|}{$\%$} \\
\hline $\begin{array}{l}\text { Olive oil } \\
\qquad(1 \mathrm{ml} / \mathrm{kg}, \mathrm{s.c} .)\end{array}$ & $364 \pm 63$ & $1944 \pm 383$ & $8.7 \pm 0.4$ & $3.7 \pm 0.3$ \\
\hline $\begin{array}{l}\text { Indomethacin } \\
(3 \mathrm{mg} / \mathrm{kg}, \mathrm{s.c} .)\end{array}$ & $\begin{array}{c}89 \pm 18 \\
(0.005)\end{array}$ & $\begin{array}{l}489 \pm 185 \\
(0.005)\end{array}$ & $\begin{array}{c}5.9 \pm 0.5 \\
(0.001)\end{array}$ & $\begin{array}{c}2.5 \pm 0.1 \\
(0.001)\end{array}$ \\
\hline $\begin{array}{l}\text { Meclofenamate } \\
(2 \mathrm{mg} / \mathrm{kg}, \text { s.c. })\end{array}$ & $\begin{array}{l}163 \pm 34 \\
(0.02)\end{array}$ & $\begin{array}{l}579 \pm 134 \\
(0.01)\end{array}$ & $\begin{array}{c}4.4 \pm 0.1 \\
(0.001)\end{array}$ & $\begin{array}{l}1.9 \pm 0.1 \\
(0.001)\end{array}$ \\
\hline
\end{tabular}

Each value represents the mean \pm SEM for seven determinations. Statistical significance compared with control is indicated in parentheses.
$(P<0.01)$, whereas meclofenamate caused a $27 \%$ reduction $(P<0.05)$.

Fig. 1 illustrates the effect of indomethacin on angiotensin-induced aldosterone release. Angiotensin II and III were equipotent in stimulating a dose-related increase in serum aldosterone. Indomethacin reduced the control aldosterone levels from $2.4 \pm 0.3 \mathrm{ng} / \mathrm{dl}$ to $1.2 \pm 0.4 \mathrm{ng} / \mathrm{dl}(P<0.02)$. Additionally, in similarly infused animals pretreated with indomethacin $3 \mathrm{mg} /$ $\mathrm{kg}$, the steroidogenic responses to angiotensin II and III were reduced by 45 and $63 \%$, respectively, as indicated by the shift in the dose-response curve to the right. Further reductions of the steroidogenic responses were achieved with a $10 \mathrm{mg} / \mathrm{kg}$ dose of indomethacin. This higher dose caused a 63 and $73 \%$ suppression of angiotensin II- and III-induced aldosterone release, respectively.

The effects of meclofenamate on angiotensin-induced steroidogenesis is shown in Fig. 2. Unlike indomethacin, meclofenamate failed to alter the control or the angiotensin II-induced aldosterone release. However, the response to angiotensin III was inhibited by $99 \%$ $(P<0.001)$.

The effects of indomethacin were also tested in sodium-depleted rats (Fig. 3). After sodium depletion, the control serum aldosterone levels increased from $2.4 \pm 0.3$ to $74 \pm 6 \mathrm{ng} / \mathrm{dl}(P<0.001)$, and serum renin activity increased from $3.1 \pm 0.3$ to $12.1 \pm 1.8 \mathrm{ng} / \mathrm{ml}$ per $\mathrm{h}$ $(P<0.001)$. Indomethacin $(3 \mathrm{mg} / \mathrm{kg})$ decreased the serum aldosterone by $29 \%$ without altering the serum renin activity. Additionally, the response of serum aldosterone to angiotensin II was partially inhibited from $164 \pm 8$ to $126 \pm 4 \mathrm{ng} / \mathrm{dl}(P<0.05)$, whereas the response to angiotensin III was completely suppressed to a value identical to that observed with indomethacin alone $(116 \pm 5$ to $53 \pm 10 \mathrm{ng} / \mathrm{dl}[P<0.01])$.

Adrenal cell suspensions. In adrenal cell suspensions, angiotensin II and III caused a dose-related increase in aldosterone release with angiotensin III being $53 \%$ as potent as angiotensin II (Figs. 4 and 5).

TABLE III

Effect of Prostaglandin Synthesis Inhibitors on Serum Renin Activity

\begin{tabular}{|c|c|c|}
\hline \multirow[b]{2}{*}{ Treatment } & \multicolumn{2}{|c|}{ Serum renin activity } \\
\hline & Normal & $\begin{array}{l}\text { Sodium } \\
\text { deplete }\end{array}$ \\
\hline & \multicolumn{2}{|c|}{ ng angiotensin $\mathrm{l} / \mathrm{ml} / \mathrm{h}$} \\
\hline Olive oil (1 ml/kg, s.c.) & $3.10 \pm 0.28$ & $12.1 \pm 1.8$ \\
\hline Indomethacin $(3 \mathrm{mg} / \mathrm{kg}$, s.c.) & $1.76 \pm 0.28 t$ & $10.7 \pm 1.0$ \\
\hline Meclofenamate ( $2 \mathrm{mg} / \mathrm{kg}$, s.c.) & $2.26 \pm 0.17^{*}$ & - \\
\hline
\end{tabular}

Each value represents the mean \pm SEM for 12 animals.

$* P<0.05$.

$\ddagger P<0.01$ compared to olive oil control. 


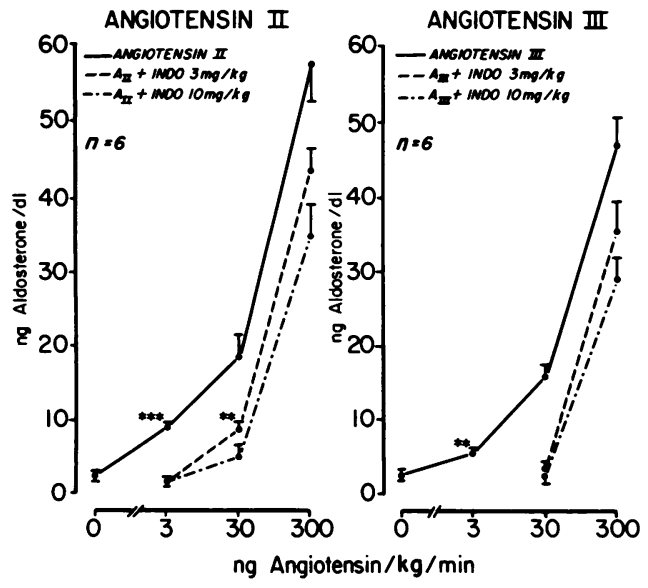

FIGURE 1 The effect of indomethacin (Indo) (3 and $10 \mathrm{mg}$ / $\mathrm{kg}$ s.c.) on the release of aldosterone stimulated by angiotensin II (left) and III (right) in conscious rats. Each point represents the mean \pm SEM for six rats. (**) $P<0.01$ and (***) $P<0.001$ compared to control.

Indomethacin $(1 \mu \mathrm{g} / \mathrm{ml}$ ) decreased the basal aldosterone release by $29 \%$ and reduced the release of $\mathrm{PGE}_{2}$ from $709 \pm 84$ to $381 \pm 10 \mathrm{pg} / 10^{6}$ cells per $\mathrm{h}$. In addition, indomethacin inhibited the steroidogenic effects of angiotensin II and III by 81 and 93\%, respectively (Fig. 4). Unlike indomethacin, meclofenamate $(1 \mu \mathrm{g} / \mathrm{ml})$ failed to alter basal or angiotensin II-stimulated aldosterone release (Fig. 5). However, angiotensin III-stimulated aldosterone release was inhibited by $86 \%$ by meclofenamate.

\section{DISCUSSION}

Recent studies have demonstrated that $\mathrm{PGE}_{1}$ and $\mathrm{PGE}_{2}$ stimulate the release of aldosterone, whereas $\mathrm{PGF}_{1 \alpha}$ and $\mathrm{PGF}_{2 \alpha}$ in similar studies inhibit its release $(6,7)$. Additionally, the steroidogenic effect of $\mathrm{PGE}_{1}$ was found to be additive with those of angiotensin II (6), suggesting that a dual mechanism involving these two hormone systems may be operative in the control of aldosterone secretion.

A number of investigators have attempted to probe this prostaglandin-renin-angiotensin interaction by activating the renin-angiotensin component with furosemide while also inhibiting the prostaglandin component with prostaglandin synthesis inhibitors $(15,16)$. In these studies, indomethacin inhibited the increase in aldosterone secretion caused by furosemide as well as the increase in renin. Similarly, in patients with hyperreninemia and hyperaldosteronism caused by Bartter's syndrome, prostaglandin synthesis inhibitors also decreased the plasma renin activity and the plasma aldosterone levels (17). Thus, although these studies demonstrated that prostaglandin synthesis inhibitors reduce the secretion of aldosterone,

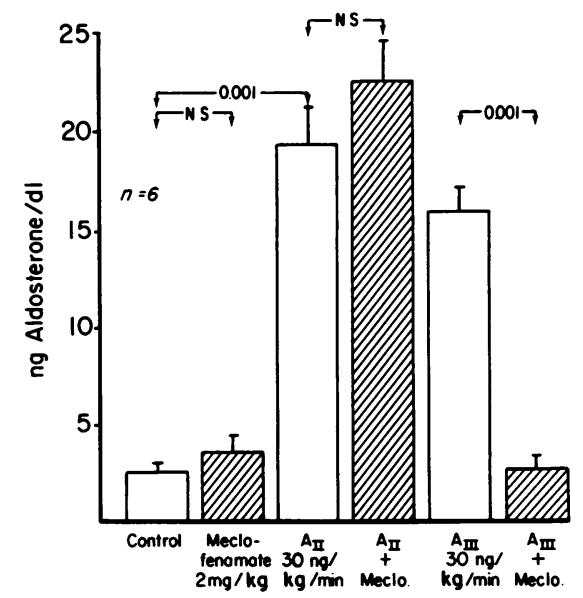

Figure 2 The effect of meclofenamate (Meclo.) $(2 \mathrm{mg} / \mathrm{kg}$ s.c.) on angiotensin II (AII)- and III (AIII)-induced aldosterone release in conscious rats. Each point represents the mean $\pm S E M$ for six rats. Levels of statistical significance are indicated by the brackets above the compared bars.

the effect was apparently secondary to the suppression of renin release and failed to definitively demonstrate the contribution of prostaglandins to adrenal steroidogenesis.

In contrast, our data indicate that inhibitors of prostaglandin synthesis influence the renin-angiotensin-aldosterone system by not only decreasing the release of renin, but also by reducing angiotensin-

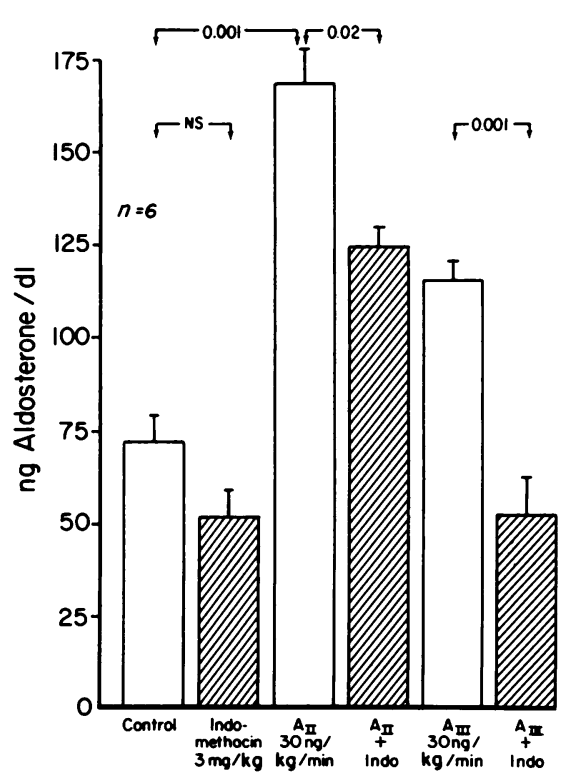

Figure 3 The effect of indomethacin (Indo) (3 mg/kg s.c.) on angiotensin II (AII)- and III (AIII)-induced aldosterone release in sodium-depleted, conscious rats. Each point represents the mean \pm SEM for six rats. Levels of statistical significance are indicated by the brackets above the compared bars. 


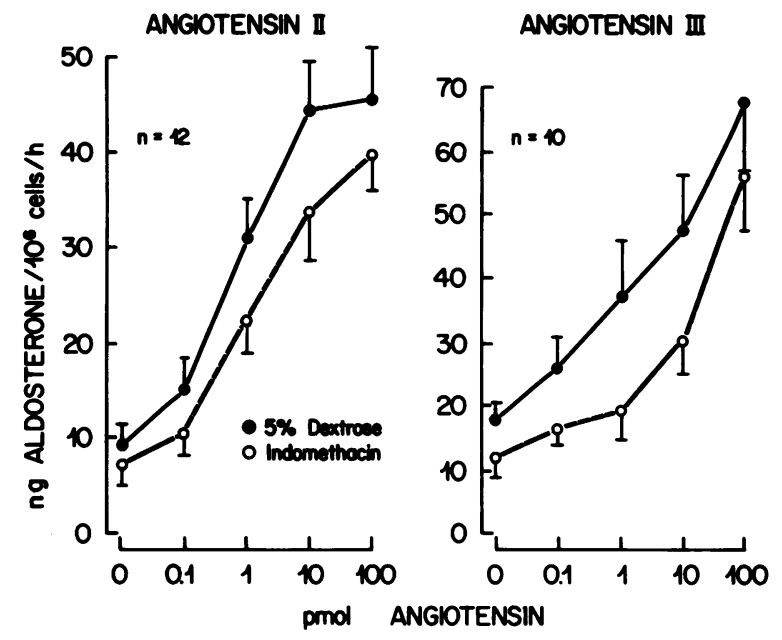

Figure 4 The effect of indomethacin $(1 \mu \mathrm{g} / \mathrm{ml})$ on angiotensin II- and III-induced aldosterone release in rat adrenal cortical cell suspensions. Each point represents the mean \pm SEM for 10-12 preparations.

induced aldosterone release. Indomethacin, in doses that suppressed adrenal prostaglandin production, inhibited the basal aldosterone release as well as that stimulated by angiotensin II and III in normal and sodium-depleted rats and adrenal cell suspensions. Meclofenamate, another prostaglandin synthesis inhibitor, failed to alter the basal or angiotensin IIinduced aldosterone release but completely inhibited that caused by angiotensin III. Inasmuch as angiotensin II and III stimulate the synthesis and release of prostaglandins in several tissues (3-5), our findings suggest that the angiotensins also may stimulate the formation of adrenal prostaglandins, which in turn

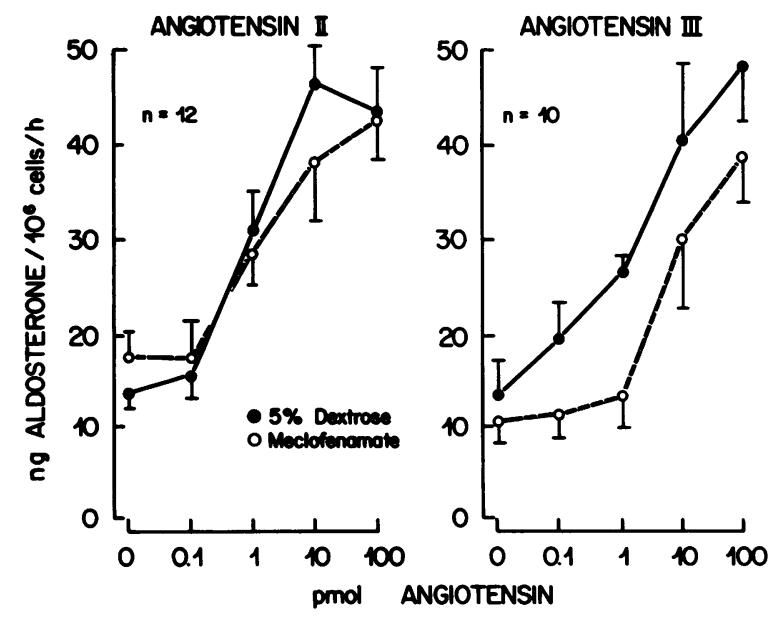

Figure 5 The effect of meclofenamate $(1 \mu \mathrm{g} / \mathrm{ml})$ on angiotensin II- and III-induced aldosterone release in rat adrenal cortical cell suspensions. Each point represents the mean \pm SEM for 10-12 preparations. either augment or mediate the angiotensin-induced aldosterone release. It should be mentioned, however, that this conclusion is based on indirect evidence using inhibitors of prostaglandin synthesis and further direct evidence is required. Additionally, the steroidogenic responses to angiotensin III were reduced to a greater extent than those of angiotensin II. These differences were most apparent in normal rats receiving meclofenamate and sodium-depleted rats receiving indomethacin. These findings suggest that angiotensin II and III may act in the adrenal, as in vascular smooth muscle (18), via different mechanisms with angiotensin III being more dependent on the intra-adrenal synthesis of prostaglandins for its steroidogenic effects than angiotensin II. Along these lines, Devynck et al. (19) have identified an angiotensin receptor in the rat adrenal that preferentially binds angiotensin III and can be distinguished from the receptor for angiotensin II.

The reasons for the differences between indomethacin and meclofenamate inhibition of basal and angiotensin II-stimulated aldosterone release in our studies is unclear. However, because similar results have been obtained in studies using isolated adrenal cortical cell suspensions, the effects are apparently caused by differences in the sensitivity of the adrenal cortex to the two inhibitors or caused by a direct action of the drugs on adrenal steroidogenesis. Along these lines, Spät et al. (20) also found differences between the effects of indomethacin and aspirin on ACTH-induced steroidogenesis and suggested that aspirin may act by some mechanism other than inhibition of prostaglandin synthesis.

Frohlich et al. (15) also studied the effect of indomethacin on angiotensin II-induced steroidogenesis in five hypertensive patients. Unlike our findings, indomethacin failed to modify the aldosterone release caused by angiotensin II but did reduce the basal aldosterone levels. It should be mentioned that those studies were performed in patients with postmalignant hypertension and care should be taken in extrapolating these findings to normal subjects. For example, in these patients, unlike normal subjects, angiotensin II infusions also failed to suppress plasma renin activity. Golub et al. (21) reported in normal subjects that indomethacin failed to alter angiotensin II stimulation of aldosterone secretion. However, as first stated by Norbiato et al. (22), upon recalculation of their data, we found that indomethacin significantly reduced the angiotensin-induced aldosterone release from $19.7 \pm 3.2$ to $11.7 \pm 2.4 \mathrm{ng} / \mathrm{dl}(P<0.05)$. These changes are, thus, consistent with our findings in conscious rats.

In summary, our findings and those of others indicate that prostaglandins modulate the effects of the reninangiotensin-aldosterone system at virtually all levels 
tested. Specifically, tissue prostaglandins appear involved in: $(a)$ controlling the release of renin (Table III; [15-17, 23]); (b) modulating or mediating angiotensin II and III steroidogenesis (Figs. 1-5; [6, 7, 21]); (c) antagonizing the vasoconstrictor action of angiotensin II (24); and (d) modulating the effect of aldosterone on sodium transport (25).

\section{ACKNOWLEDGMENTS}

The authors are grateful to Ms. Ellen Rudisill for her secretarial assistance. We also appreciate the gifts of the antialdosterone antibody provided by the National Institute of Arthritis, Metabolism, and Digestive Diseases, the antiangiotensin I antiserum provided by Dr. Knud Poulsen of the University of Copenhagen, the prostaglandin standards provided by Dr. J. E. Pike of the Upjohn Co., Kalamazoo, Mich., and the meclofenamate provided by Dr. C. C. Beck of Parke, Davis \& Co.

Support for these studies was provided by grants from the National Heart and Lung Institute (HL21066 and 12677).

\section{REFERENCES}

1. Campbell, W. B., J. M. Schmitz, and H. D. Itskovitz. 1977. (Des-Asp ${ }^{1}$ angiotensin I: a study of its pressor and steroidogenic activities in conscious rats. Endocrinology. 100: 46-51.

2. Campbell, W. B., J. M. Schmitz, and H. D. Itskovitz. 1979. Effect of sodium depletion on the steroidogenic and pressor actions of angiotensin in the rat. Clin. Sci. 65: 325-333.

3. McGiff, J. C., K. Crowshaw, N. A. Terragno, and A. J. Lonigro. 1970. Release of a prostaglandin-like substance into renal venous blood in response to angiotensin II. Circ. Res. 26, 27 (Suppl. I): 121-130.

4. Blumberg, A. L., S. Denny, K. Nishikawa, E. Pure, G. R. Marshall, and P. Needleman. 1976. Angiotensin IIIinduced prostaglandin release. Prostaglandins. 11: 195197.

5. Blumberg, A. L., K. Nishikawa, S. E. Denny, G. R. Marshall, and P. Needleman. 1977. Angiotensin (AI, AII, AIII) receptor characterization: correlation of prostaglandin release with peptide degradation. Circ. Res. 41: 154158.

6. Saruta, T., and N. M. Kaplan. 1972. Adrenocortical steroidogenesis: the effects of prostaglandins. J. Clin. Invest. 51: 2246-2251.

7. Honn, K. V., and W. Chann. 1976. Role of prostaglandins in aldosterone production by the human adrenal. Biochem. Biophys. Res. Commun. 72: 1319-1326.

8. Vane, J. R. 1971. Inhibition of prostaglandin synthesis as a mechanism of action for aspirin-like drugs. Nat. N. Biol. 231: 232-235.

9. Dray, F., B. Charbonne, and J. Malouf. 1975. Radioimmunoassay of prostaglandin $F_{\alpha}, E_{1}$, and $E_{2}$ in human plasma. Eur. J. Clin. Invest. 5: 311-318.

10. Sarstedt, C. A., E. D. Vaughan, and M. J. Peach. 1975. Selective inhibition by Des-1-Asp-8-ile angiotensin II or the steroidogenic response to restricted sodium intake in the rat. Circ. Res. 37: 350. (Abstr.)

11. Gomez-Sanchez, C., D. C. Kem, and N. M. Kaplan. 1973. A radioimmunoassay for plasma aldosterone by immunologic purification. J. Clin. Endocrinol. Metab. 36: 795798.

12. Poulsen, K., and J. Jorgensen. 1974. An easy radioimmunological micro-assay of renin activity, concentration and substrate in human and animal plasma and tissue based on angiotensin I trapping by antibody. J. Clin. Endocrinol. Metab. 39: 816-825.

13. Jaffe, B. M., and H. R. Behrman. 1974. Prostaglandins $\mathrm{E}, \mathrm{A}$, and F. In Methods in Hormone Radioimmunoassay. B. H. Jaffe and H. R. Behrman, editors. Academic Press, Inc., New York. 19-34.

14. Snedecor, G. W., and W. G. Cochran. 1967. Statistical Methods. Iowa State University Press, Ames, Iowa. 432.

15. Frohlich, J. C., J. W. Hollifield, J. C. Dormois, B. L. Frohlich, H. Seyberth, A. M. Michelakis, and J. A. Oates. 1976. Suppression of plasma renin activity by indomethacin in man. Circ. Res. 39: 447-452.

16. Patak, R. V., B. K. Mookerjee, C. J. Bentzel, P. E. Hysert, M. Babej, and J. B. Lee. 1975. Antagonism of the effects of furosemide by indomethacin in normal and hypertensive man. Prostaglandins. 10: 649-659.

17. Gill, J. R., J. C. Frohlich, R. E. Bowden, A. A. Taylor, H. R. Keiser, H. W. Seyberth, J. A. Oates, and F. C. Bartter. 1976. Bartter's syndrome: a disorder characterized by high urinary prostaglandins and a dependence of hyperreninemia on prostaglandin synthesis. Am. J. Med. 61: 43-51.

18. Ackerly, J. A., A. F. Moore, and M. J. Peach. 1977. Demonstration of different contractile mechanisms for angiotensin II and des-Asp'-angiotensin II in rabbit aortic strips. Proc. Natl. Acad. Sci. U. S. A. 74: 57255728.

19. Devynck, M-A., M-G. Pernollet, P. G. Matthews, M. C. Khosla, F. M. Bumpus, and P. Meyer. 1977. Specific receptors for des-Asp'-angiotensin II ("angiotensin III") in rat adrenals. Proc. Natl. Acad. Sci. U. S. A. 74: 40294032.

20. Spät, A., P. Kiklos, F. A. Antoni, K. Nagy, and K. Sziranyi. 1977. Effect of prostaglandin synthetase inhibitors on basal and ACTH-stimulated steroid synthesis by separated adrenocortical zones. J. Steroid. Biochem. 8: 293-298.

21. Golub, M. S., P. F. Speckart, P. K. Zia, and R. Horton. 1976. The effect of prostaglandin $A_{1}$ on renin and aldosterone in man. Circ. Res. 39: 574-579.

22. Norbiato, G., M. Bevilacqua, J. Raggi, P. Micossi, C. Moroni, and A. Fasoli. 1978. Effect of prostaglandin synthetase inhibitors on renin and aldosterone in man on normal or low sodium diet. Acta Endocrinol. 85: 577.

23. Campbell, W. B., R. M. Graham, and E. K. Jackson. 1979. Role of renal prostaglandins in sympathetically mediated renin release in the rat. J. Clin. Invest. 64: 448-456.

24. Aiken, J. W., and J. R. Vane. 1973. Intrarenal prostaglandin release attenuates the renal vasoconstrictor activity of angiotensin. J. Pharmacol. Exp. Ther. 184: 678-687.

25. Yorio, T., and P. J. Bentley. 1978. Phospholipase A and the mechanism of action of aldosterone. Nature (Lond.). 271: 79-81. 